В законодательстве Российской Империи первоначально был установлен общий предельный срок найма недвижимого имущества - 12 лет (с некоторыми исключениями для отдельных местностей Российской Империи и для найма земли). Однако такой короткий предельный срок найма не был выгоден для лиц, осуществлявших значительные капиталовложения в нанимаемую недвижимость. С учетом этого в 1911 г. общий предельный срок имущественного найма был увеличен до 36 лет.

В рассматриваемый период размер платы за наем жилья определялся исключительно по соглашению сторон договора. В период 1916-1917 гг. нормативными правовыми актами Правительства наймодателям было запрещено повышать цены на жилые помещения. [6].

На смену Свода законов гражданских готовилось Гражданское уложение Российской Империи, разработка которого велась более десяти лет. В конце XIX в. был опубликован проект книги V Гражданского уложения - «Об обязательствах», а также комментарии к ней [7]. В 1915 г. указанный проект после доработки был внесен в Государственную Думу, однако из-за событий Первой мировой войны он не был принят в качестве закона, так и оставшись на уровне законопроекта [8].

$$
\text { *** }
$$

1. Кодификация российского гражданского права. Ектеринбург,2003.

2. Победоносцев К.П. Курс гражданского права. Т. 3. (По изданию 1896 г.). М., 2003. 350 с.

3. Кавелин К.Д. Собрание сочинений. Т. 4. СПб., 1898. 710 с.

4. Шершеневич Г.Ф. Учебник русского гражданского права. М., 1995. 358 с.

5. Законы гражданские с разъяснениями Правительствующего Сената и комментариями русских юристов. Кн. 3. (Составитель Тютрюмов И.М.). (По изд. 1911 г.). М., 2004.

6. Постановления от 27 августа 1916 г. и от 5 августа 1917 г. (Аскна-зий С.П. Советское жилищное право. М., 1940. С. 18; Законы гражданские с разъяснениями Правительствующего сената и комментариями русских юристов. Кн. 3. (Составитель Тютрюмов И.М.). (По изданию 1911 г.). М.,

7. Гражданское уложение. Проект утвержденной Редакционной комиссии по составлению Гражданского уложения. Книга пятая. Обязательства. С объяснениями. СПб., 1899.

8. Тиле А.А. Проект Гражданского уложения России 1905-1913 гг. (Общая характеристика). М., 1984.

\title{
Федорова А.С. \\ Прокурорский надзор за соблюдением законности в оперативно-розыскной деятельности: проблемные аспекты
}

Санкт-Петербургский юридический институт (филиал) федерального государственного казенного образовательного учреждения высшего образования «Академия Генеральной прокуратуры Российской Федераџии»

doi:10.18411/spc-20-11-2017-18

(Россия, Санкт-Петербург)

idsp: 000001:spc-20-11-2017-18

Оперативно-розыскная деятельность с древних времён характеризуется как особый вид правоохранительной деятельности государства, направленный на противодействие преступности и обеспечение безопасности посредством применения полицейскими органами специфических способов, основанных на гласных и негласных средствах и методах получения информации. Безусловно, большинство из таких средств и методов затрагивают и в какой-то степени ограничивают права и свободы граждан, закреплённые в Конституции РФ, однако без их использования бороться с преступными проявлениями на практики весьма сложно.

Впервые организационные и правовые основы данного вида правоохранительной деятельности государства на законодательном уровне были закреплены 13 марта 1992 года, с принятием Закона Российской Федерации "Об оперативно-розыскной деятельности в Российской Федерации". При этом сегодня 
действующим нормативно-правовым актом в рассматриваемой области правоотношений является Федеральный закон №144-Ф3 "Об оперативно-розыскной деятельности", принятый Государственной Думой Российской Федерации 5 июля 1995 года.

В свою очередь главенствующую роль в обеспечении эффективного и точного исполнения действующих на территории России законов играет прокурорский надзор. Так, согласно Федеральному закону «О прокуратуре Российской Федерации»,главной функцией прокурора является осуществление надзора за соблюдением Конституции РФ и исполнением законов, действующих на территории страны. Указанный надзор осуществляется в целях обеспечения верховенства закона, единства и укрепления законности, защиты прав и свобод человека и гражданина, а также охраняемых законом интересов общества и государства.

Важно отметить, что прокурорский надзор за исполнением законов органами, осуществляющими оперативно-розыскную деятельность, как в теории, так и на практике считается одним из основных направлений деятельности органов прокуратуры. В связи с чем Ю.Я. Чайкой на заседаниях коллегий Генеральной прокуратуры РФ неоднократно провозглашалась приоритетность прокурорского надзора за законностью в ОРД и необходимость его усиления.

Между тем сложившийся ситуационный подход к осуществлению прокурорского надзора за исполнением законов в рассматриваемой области правоотношений обуславливает наличие проблем в практической деятельности. Особую актуальность при этом имеют проблемы, связанные с определением предмета прокурорского надзора за ОРД, а также с определением перечня полномочий, которым наделён прокурор при его осуществлении.

Подобное положение вещей, полагаю, не должно иметь место, поскольку в процессе осуществления оперативно-розыскной деятельности затрагиваются как уже было отмечено важнейшие права и свободы граждан, гарантированные Конституцией РФ.

Необходимо отметить, что на сегодняшний день прокурорский надзор за исполнением законов органами, осуществляющими ОРД, является составной частью отрасли прокурорского надзора - за исполнением законов органами, осуществляющими оперативно-розыскную деятельность, дознание и предварительное следствие, которая предусмотрена главой 3 Федерального закона «О прокуратуре Российской Федерации». Вместе с тем дискуссионным на протяжении длительного времени остаётся вопрос относительно законодательного определения предмета прокурорского надзора за исполнением законов органами, осуществляющими оперативно-розыскную деятельность. Так, критике многих учёных подвергается определение единого предмета надзора за исполнением законов органами, осуществляющими ОРД, дознание и предварительное следствие поскольку, в таком случае остаются неохваченными существенные различия оперативно-розыскной и уголовно-процессуальной деятельности, а также специфика их правового регулирования. В связи с чем, по моему мнению, при определении предмета надзора за ОРД, прежде всего необходимо исходить из закреплённых законодателем задач и особенностей, характерных для оперативно-розыскной деятельности, потому как именно законность деятельности по решению поставленных задач и должна выступать предметом надзора. В свою очередь ст. 29 Ф3 «О прокуратуре» указанные особенности не учитывает, а предмет прокурорского надзора по большей мере соотносится с деятельностью органов дознания и предварительного следствия. По мнению Козусева А.Ф., таким образом законодателем «проигнорирована сущность такого специфического и самостоятельного вида деятельности, какой является оперативно-розыскная деятельность». Более того, само понимание надзора за законностью осуществления ОРД в качестве одной из составляющих прокурорского надзора за исполнением законов органами 
предварительного расследования первоначально сводит к минимуму его значимость среди набора инструментов, используемых в целях обеспечения защиты прав и законных интересов граждан, а также борьбы с преступностью.

На основании изложенного, полагаю, что весьма перспективной является позиция Никитина Е.Л., который отмечает, что надзор за законностью оперативнорозыскной деятельности и надзор за законностью процессуальной деятельности имеют определённую специфику и самостоятельное значение, что служит основанием для их потенциального разделения на отдельные отрасли и выделения самостоятельных предметов прокурорского надзора.

Спорным моментом по сей день остаётся и вопрос относительно перечня полномочий прокурора при осуществлении надзора за законностью ОРД. Многие учёные по данному вопросу занимают разные позиции. Так, существуют различные точки зрения относительно властно-распорядительного характера полномочий прокурора в рассматриваемой сфере правоотношений.

Перечень полномочий, которыми наделён прокурор при осуществлении надзора за соблюдением законности в оперативно-розыскной деятельности содержится в нескольких источниках.

Федеральный закон «О прокуратуре Российской Федерации», а именно статья 30 содержит лишь ссылку на положения уголовно-процессуального закона и другие федеральные законы Российской Федерации, нормами которых должен определяться круг полномочий прокурора при осуществлении рассматриваемого направления надзора. Однако, к сожалению, ни УПК РФ, ни другие федеральные законы подобных положений не содержат, что указывает на существенный пробел в действующем законодательстве. Несовершенной в данном случае является и статья 21 Федерального закона "Об оперативно-розыскной деятельности", диспозиция которой опять же носит бланкетный характер и, которая не содержит формально-определённых предписаний, детально регламентирующих полномочия прокурора за исполнением законов в сфере оперативно-розыскной деятельности. Кроме того, некоторые вопросы прокурорского надзора, в том числе и полномочий отражены в приказе Генерального прокурора от 15.02.2011 №33 "Об организации прокурорского надзора за исполнением законов при осуществлении оперативно-розыскной деятельности". В частности, указывается, что деятельность уполномоченного прокурора должна быть направлена на обеспечение соблюдения прав и свобод человека и гражданина, законности при решении задач оперативно-розыскной деятельности.Отсюда совершенно справедливо следует вывод, что прокурор обязан осуществлять надзор не только за соблюдением и исполнением законов, но и посредством применения средств прокурорского надзора обеспечивать законность при решении задач оперативно-розыскной деятельности, не подменяя при этом органы ведомственного контроля.

На практике проблема недостаточной регламентации полномочий прокурора в рассматриваемой сфере разрешается путём использования в ходе проверок поднадзорных оперативно-розыскных органов полномочий, закреплённых в статьях 22 и 27 Федерального закона «О прокуратуре Российской Федерации». Вместе с тем, полагаю такой выход из ситуации, нельзя признать верным. Подобного мнения придерживаются также Никитин Е.Л., Дытченко Г.В., которые отмечают в своей работе, что применение «общенадзорных» средств выявления и устранения нарушений законов в сфере оперативно-розыскной деятельности не является достаточно эффективным, поскольку не учитывает специфику деятельности оперативнорозыскных органов и обедняет арсенал средств прокурорского реагирования.В связи с этим в целях обеспечения прав и законных интересов граждан в сфере оперативнорозыскной деятельности многими исследователями в области прокурорского надзора, а также практическими работниками, указывается на необходимость расширения полномочий прокурора. 
Таким образом, изложенное даёт основание утверждать, что подвергнутые в настоящей работе анализу проблемы, заслуживают внимания не только на теоретическом уровне, но и требует своего разрешения посредством нормотворчества. Однако в первую очередь, полагаю, целесообразным будет все-таки признать, что прокурорский надзор за исполнением законов органами, осуществляющими ОРД, является самостоятельной отраслью надзора в структуре деятельности прокуратуры Российской Федерации.

$$
\text { *** }
$$

1. Об организации прокурорского надзора за исполнением законов при осуществлении оперативнорозыскной деятельности: приказ Генерального прокурора Рос. Федерации от 15 февр. 2011 г. № 33. П. 4.

2. Федеральный закон от 17 января 1992 г. N 2202-1 "О прокуратуре Российской Федерации" (по состоянию на 25.10.2016) // СПС "КонсультантПлюс"

3. Федеральный закон от 12 августа 1995 г. N 144-Ф3 "Об оперативно-розыскной деятельности" (по состоянию на 06.07.2016) //СПС "КонсультантПлюс"

4. Доклад Ю. Я. Чайки на расширенном заседании коллегии Генеральной прокуратуры Российской Федерации / Сайт Генеральной прокуратуры Российской Федерации. URL: http://genproc.gov.ru/genprokuror/appearances/document-493/

5. Козусев А. Ф. Надзор за исполнением законов в оперативно-розыскной деятельности - отрасль прокурорского надзора // Проблемы теории и практики прокурорского надзора в современных условиях: тезисы науч.-практ. конференции /Акад. Генеральной прокуратуры Рос. Федерации. М., 2005. Ч. 1. С. 75 .

6. Никитин Е.Л. О задачах оперативно-розыскной деятельности и особенностях предмета прокурорского надзора за исполнением законов в ОРД// Криминалистъ. 2015. №2 (17). С.34-39.

7. Никитин Е.Л., Дытченко Г.В. Современная парадигма прокурорского надзора за исполнением законов в оперативно-розыскной деятельности // КриминалистЪ. 2014. №1 (14). С. 73-80.

\section{Халиулова И.Р. \\ Особенности правовой основы реформы Д.А. Милютина 1860-1870-х гг. В области военного образования}

Ульяновский государственньій университет (Россия, Ульяновск)

doi:10.18411/spc-20-11-2017-19

idsp: 000001:spc-20-11-2017-19

\section{Аннотация}

В статье дана характеристика реформаторской деятельности военного министра Д.А. Милютина в сфере военного образования. Раскрываются причины проведения реформ 60-70-х гг. XIX в., перечислены основные нормативно-правовые источники реформы военного образования.

Ключевые слова: военная реформа Александра II, Д.А. Милютин, военное образование, военные гимназии и прогимназии, военные и юнкерские училища.

Социально-экономический кризис в Российской империи, поразивший основные сферы жизнедеятельности российского обществав 40-50-х гг. XIX в. отразился, в том числе, и на состоянии русской армии, что предопределило поражение России в Крымской войне 1853-1855 гг.

Наряду с другими объективными и субъективными условиями и факторами, предопределившими деградацию русской армии в первой половине XIX в., необходимо выделить сознательный отказ Императора от национальной военной стратегии, а также его ориентацию на чуждые национальной военной традиции принципы подготовки вооружённых сил.

Крымская война стала суровым испытанием для всей военной системы Российского государства, в том числе, для системы подготовки офицерских кадров. Её состояние на основе итогов войны образно, но в то же время вполне объективно оценил 